\title{
Synthesis and characterization of a cysteine xyloglucan conjugate as mucoadhesive polymer
}

\author{
Mangesh Bhalekar ${ }^{1, *}$, Savita Sonawane ${ }^{2}$, Shamkant Shimpi ${ }^{3}$

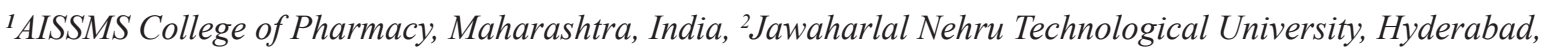 \\ ${ }^{3}$ APL Research Centre, Aurobindo Pharma Ltd., Hyderabad
}

\begin{abstract}
The aim of this study was to improve the mucoadhesive potential of xyloglucan polymer by the covalent attachment of cysteine as thiol moiety. The parent polymer xyloglucan was chemically modified by introducing sulphydryl bearing compound L-cysteine $\mathrm{HCl}$. Different batches of xyloglucan-cysteine conjugates were prepared at varying reaction $\mathrm{pH}(2-6)$ and evaluated for optimum thiol incorporation, disulphide group content, swelling behavior, rheological properties and mucoadhesive properties. The obtained conjugates characterized in vitro by quantification of immobilized thiol groups; showed maximum thiol incorporation on xyloglucan $(7.67 \pm 0.14 \%)$ at $\mathrm{pH} 5$. The disulphide group content was found maximum $(2.83 \pm 0.12)$ at $\mathrm{pH}$ 6. The water uptake at end of $4 \mathrm{~h}$ was 5.0 for xyloglucan and was found to decrease in thiolated derivatives with increase in thiolation. Mucoadhesion studies revealed that mucoadhesion of xyloglucan-cysteine conjugate increased more than twice compared to the unmodified polymer. The viscosity of thiomer was more than that of xyloglucan because of formation of disulphide bonds.
\end{abstract}

Uniterms: Mucoadhesion. Thiomer. Xyloglucan. L-cysteine HCl.

\begin{abstract}
O objetivo deste estudo foi melhorar o potencial mucoadesivo do polímero xiloglicano pela ligação covalente de cisteína como unidade de tiol. O polímero xiloglicano foi quimicamente modificado pela introdução de cloridrato de cisteína como grupo contendo sulfidrila. Prepararam-se diferentes lotes de conjugados cisteína-xiloglicano em $\mathrm{pH}$ variando de 2 a 6 , avaliando-se a incorporação ótima de tiol, o conteúdo de dissulfeto, o comportamento de inchamento, as propriedades reológicas e mucoadesivas. Os conjugados obtidos foram caracterizados in vitro pela quantificação de grupos tiol, mostrando máxima incorporação na xiloglicana $(7.67 \pm 0.14 \%)$ em pH 5. O conteúdo de grupos dissulfeto foi máximo $(2.83 \pm 0.12)$ em $\mathrm{pH} 6$. O índice de inchamento em \% no fim de $4 \mathrm{~h}$ foi 83.87 para o xiloglicano e diminuiu para os derivados tiolados. O conteúdo foi mínimo para TH2 (78.26), aumentou pouco até TH5 (83.33) e diminuiu, posteriormente, para TH6 (80.13). Os estudos de mucoadesão revelaram que o conjugado xiloglicano-cisteína aumentou mais que duas vezes comparativamente ao polímero não modificado. A viscosidade do tiômero foi maior do que a do xiloglicano devido à formação das ligações dissulfeto.
\end{abstract}

Unitermos: Mucoadesão. Tiômero. Xiloglicano. Cloridrato de L-cisteína

\section{INTRODUCTION}

The concept of mucoadhesion was pioneered in the 1980s which led to formulation of mucoadhesive delivery systems to reduce the frequency of dosing by enhancing gastric residence and improving patient-compliance. In addition, mucoadhesive polymers are able to increase

*Correspondence: Mangesh R. Bhalekar. AISSMS College of Pharmacy. Kennedy Road, Pune 410001. Maharashtra, India. E-mail: mrbhalekar@gmail.com the epithelial permeability for many drugs because of intensified contact to the mucosa (Borchard, Lueben et al., 1996) and can exclude an enzymatic degradation of perorally administered (poly) peptide drugs during their passage between the delivery system and the mucosa (Bernkop-Schnürch, Schwarz, Kratzel, 1997).

It is observed that the traditionally used mucoadhesive polymers provide mucoadhesion by noncovalent bonds to the mucus (such as hydrogen bonds and ionic interaction) which are relatively weak. This is 
thought to be not sufficient to guarantee the localization of a drug delivery system at a given target site (Lehr, 1994; Tirosh, 1994). Numerous attempts to improve the adhesive properties of polymers; led to synthesis of 'thiolated' polymers or so-called thiomers have proven to be a promising new class of polymeric excipients in mucoadhesive drug delivery system. Thiomers are capable of forming covalent bonds leading to improved mucoadhesive properties (Bernkop-Schnürch, 1999). The thiomers process improved adhesion because of formation of disulfide bonds between thiol bearing side chains of the polymer and cysteine-rich subdomains of mucus glycoproteins (Gum Jr. et al., 1992).

Xyloglucan is a natural mucoadhesive polymer derived from the seeds of Tamarindus indica Linn., and used as a additive in the paper industry. Refined xyloglucan is used as a thickening, stabilizing and gelling agent in the food industry. The polysaccharide is composed of glucose, xylose and galactose units present in the ratio of 2.8:2.25:1.0 (Gidley et al., 1991; Glicksman, 1986). Use of xyloglucan has been reported as mucoadhesive agent in eye preparations (Ludwig, 2005) and as sustained release matrix for oral drug delivery systems (Sumathi, Ray, 2002).

The aim of this study was to synthesize thiomer of xyloglucan by attachment of cysteine and evaluate the influence of reaction $\mathrm{pH}$ on various properties of thiomer such as thiol content, disulphide content, swelling behavior, rheological properties and mucoadhesive properties.

\section{EXPERIMENTAL}

\section{Isolation of xyloglucan}

Xyloglucan was isolated as per the procedure reported in literature (Sumathi, Ray, 2002). Tamarind kernel powder $(25 \mathrm{~g}$ ) was added to $200 \mathrm{~mL}$ of cold distilled water and slurry was prepared. The slurry was poured into $800 \mathrm{~mL}$ of boiling distilled water and was heated for 20 minutes under stirring condition in a water bath at $70-80{ }^{\circ} \mathrm{C}$. The resulting slurry after keeping overnight to settle the proteins and fibers; was decanted and centrifuged at $2000 \mathrm{rpm}$ for 30 minutes. The supernatant was separated and poured into excess volume of absolute ethanol with continuous stirring. The precipitate of xyloglucan was pressed between felt, washed successively with absolute ethanol, diethyl ether and petroleum ether and then dried at $50-60{ }^{\circ} \mathrm{C}$ under vacuum. The dried material was ground and sieved to obtain powder and used as polymer for further study.

\section{Synthesis of xyloglucan-cysteine conjugates}

The covalent attachment of cysteine to xyloglucan was achieved by the formation of ester bonds between the hydroxyl group of the xyloglucan and a carboxylic acid group of the cysteine (Leitner et al., 2003; Bilicic et al., 2005). Xyloglucan-cysteine thiomer was prepared by adapting the procedure given in the literature (Constantia et al., 2001). Xyloglucan (2 g) was dissolved in $250 \mathrm{~mL}$ of de-mineralized water under constant mechanical stirring for $15 \mathrm{~min}$. This solution was stirred for $30 \mathrm{~min}$ and cysteine hydrochloride ( $4 \mathrm{~g}$ ) was added to reaction mixture in a weight-ratio of 1:2 (polymer: cysteine). In order to evaluate effect of $\mathrm{pH}$ on coupling reaction, the $\mathrm{pH}$ was adjusted using $0.1 \mathrm{~N} \mathrm{NaOH}$ to $2,3,4,5$ and 6 then reaction mixtures were incubated for $3 \mathrm{~h}$ under continuous stirring. After precipitation with acetone, the reaction product was rinsed with acetone: water $(1: 1)$ in order to remove unreacted moieties and finally washed with acetone before drying at room temperature followed by drying in a vacuum oven $\left(-600 \mathrm{~mm}\right.$ of $\left.\mathrm{Hg}, 40^{\circ} \mathrm{C}, 24 \mathrm{~h}\right)$.

\section{Characterization}

\section{Fourier transform infra-red spectroscopy}

FTIR study was performed using FT-IR spectrometer (FTIR, Jasco 460) on xyloglucan and thiomer (xyloglucancysteine conjugate) to confirm the formation of conjugate between xyloglucan and cysteine $\mathrm{HCl}$.

\section{Differential Scanning Calorimetry}

Differential scanning calorimetric (DSC) measurements on xyloglucan and thiomer were carried out to study thermal behavior (DSC 823 $3^{\mathrm{e}}$, Mettler Toledo, Melbourne, Australia). The instrument was calibrated using indium $\left(156^{\circ} \mathrm{C}\right)$, tin $\left(232^{\circ} \mathrm{C}\right)$ and zinc $\left(419.5^{\circ} \mathrm{C}\right)$ as internal standards. Samples of $4-10 \mathrm{mg}$ were placed in aluminium pans (Al-Crucibles, $40 \mathrm{Al}$ ) and sealed. The probes were heated from 30 to $300{ }^{\circ} \mathrm{C}$ at a rate of $10{ }^{\circ} \mathrm{C} /$ min under nitrogen atmosphere.

\section{Thiol group determination}

Amount of free thiol groups on the thiomer was determined by iodimetry, as per the procedure given by (Bernkop, 1999). The degree of thiolation was determined by quantifying the amount of thiol groups on the thiomer. Thiomer $\left(200 \mathrm{mg}\right.$ ) was taken in $\mathrm{I}_{2}$ flask and hydrated in sufficient amount of demineralised water. The $\mathrm{pH}$ was adjusted to 2-3 with $1 \mathrm{M} \mathrm{HCl} .10 \mathrm{~mL}$ of Standard $0.1 \mathrm{~N}$ iodine solution was added, stoppered and agitated for $10 \mathrm{~min}$. The excess $\mathrm{I}_{2}$ was titrated with standard $0.1 \mathrm{~N}$ sodium 
thiosulphate using starch solution as indicator.

Blank determination was carried out as per the procedure mentioned above excluding thiomer. The amount of thiol groups present on the thiomer was determined using formula:

$\%$ Thiol group content $=[($ Blank-Proper $) \times 0.1 \times 0.066 \times$ 100] $/ 0.1 \mathrm{x}$ weight of thiomer

\section{Disulfide group content (Constantia et al., 2001)}

The disulfide content on the thiomer was calculated by subtracting total amount of thiol groups before reduction from the total amount of thiol groups after reduction using sodium borohydride. To total amount of thiol groups on the polymer after reduction were determined as; of thiomer (200 mg) was hydrated in $\mathrm{I}_{2}$ flask using sufficient amount of demineralised water. The $\mathrm{pH}$ was adjusted with $1 \mathrm{M}$ $\mathrm{HCl}$ between 2-3 and then $0.6 \mathrm{ml}$ of a freshly prepared $3 \%$ solution of sodium-borohydride was added to the hydrated polymer in order to reduce all disulfide bonds to free thiol groups and shaken for $15 \mathrm{~min}$. Thereafter, $0.5 \mathrm{~mL}$ of $1 \mathrm{M} \mathrm{HCl}$ was added and stirred to destroy the remaining sodium-borohydride. To this mixture $10 \mathrm{~mL}$ of standard $0.1 \mathrm{~N}$ Iodine solution was added, stoppered and agitated for $10 \mathrm{~min}$. The excess $\mathrm{I}_{2}$ was titrated with standard $0.1 \mathrm{~N}$ sodium thiosulphate using starch solution as indicator. The amount of thiol groups before reduction was determined by procedure reported earlier, $\%$ Disulfide group content was determined using formula

$\%$ Disulfide group content $=[(\mathrm{B} 1-\mathrm{B} 2) \times 0.1 \times 0.066 \times 100] /$ $0.1 \mathrm{x}$ weight of thiomer

where, $\mathrm{B}_{1}=$ Blank - Burette reading after reduction; $\mathrm{B}_{2}=$ Blank - Burette reading before reduction.

\section{Water uptake studies (A Bernkop schnurch, steininger} $S, 2000)$

The study was performed on thiomer synthesized at $\mathrm{pH} 2,3,4,5$, and 6 which are designated as TH2, TH3, TH4, TH5 and TH6 respectively.

Polymer $(30 \mathrm{mg}$ ) was compressed into $5.0 \mathrm{~mm}$ diameter flat faced discs at constant pressure. The discs were placed in plastic tube with a bottom of permeable membrane. The tubes were then set in a vessel containing demineralised water at $20^{\circ} \mathrm{C}$. The tubes were removed at predetermined intervals and weighed at regular intervals after removing excess water.

\section{In vitro mucoadhesion studies}

The xyloglucan and thiomer (2 g) was converted into gel by addition of demineralised water $(5 \mathrm{~mL})$. The mucoadhesive potential of each formulation was determined by measuring the force required to detach the formulation from mucosal tissue using a modified balance method described by (Jones et al. 2000). In brief, mucus tissues were carefully removed from the intestine of sheep obtained from the local slaughterhouse. Tissues were immediately used after separation. At the time of testing, a section of mucosal tissue was secured (keeping the mucosal side out) to the upper probe using a supportive adhesive tape. The probe was attached to one side of two pan balance. The surface area of each exposed mucosal membrane was $0.785 \mathrm{~cm}^{2}$. At room temperature, fixed amount of samples of each formulation were placed on lower probe by supportive adhesive tape. The probes were equilibrated. Probe with mucus tissue was lowered until the tissue contacted the surface of the sample. The probes were connected for 2 minutes to ensure intimate contact between the tissues and the samples. The probe was then moved upwards by adding weight in pan which is present on other side of balance. The mucoadhesive force, expressed as the detachment stress in dyne $/ \mathrm{cm}^{2}$, was determined from the minimal weights that detached the tissues from the surface of each formulation using the following equation (Majithiya et al., 2006).

Detachment Stress $\left(\right.$ dyne $\left./ \mathrm{cm}^{2}\right)=\mathrm{m}^{*} \mathrm{~g} / \mathrm{A}$

where $\mathrm{m}$ is the weight added to the balance in grams; $\mathrm{g}$ is the acceleration due to gravity taken as $980 \mathrm{~cm} / \mathrm{s}^{2}$; and A the area of tissue exposed. Measurements were repeated thrice for each of the gel preparations, but before each measurement a fresh smooth gel surface was created.

\section{Viscosity measurement}

The rheological properties of xyloglucan and thiomer $(2 \% \mathrm{w} / \mathrm{v})$ solutions (TH2 ...TH6) were determined using a Brookfield Digital Viscometer model 'DV-II plus PRO', USA by adopting the following experimental conditions: temperature $25 \pm 1{ }^{\circ} \mathrm{C}, 20 \mathrm{rpm}$.

\section{RESULTS AND DISCUSSION}

\section{Isolation of xyloglucan}

The production of xyloglucan polymer was done by precipitation with ethyl alcohol. The product yield obtained after precipitation was 35 to $50 \%$ in various batches because of separation of proteins and fibers from tamarind kernel powder. The obtained xyloglucan (Figure 1) was used for further study. 


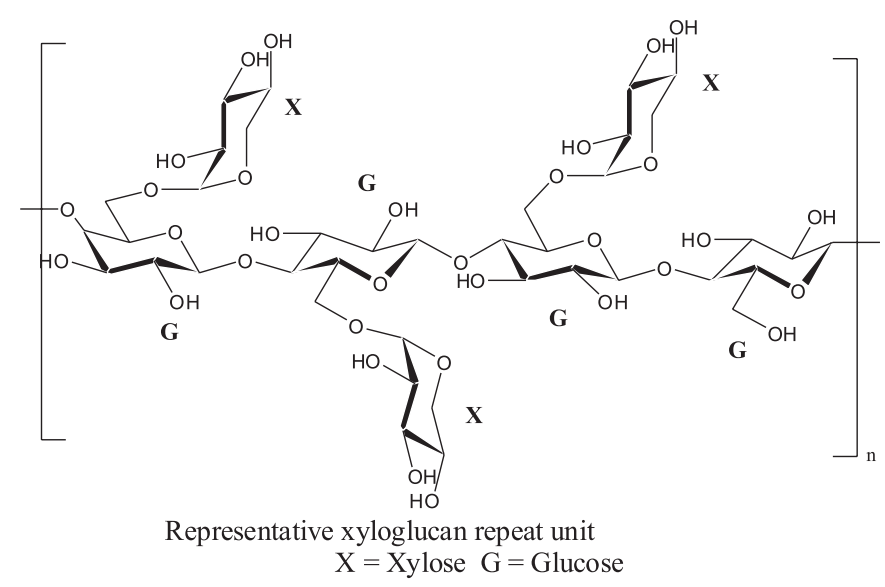

FIGURE 1 - Structure of xyloglucan.

\section{Synthesis of xyloglucan-cysteine conjugates}

The mechanism involved in the synthesis of thiomer is covalent attachment of cysteine moiety to the xyloglucan with the help of EDAC.HCl as a coupling reagent. The covalent attachment of cysteine to xyloglucan was achieved by the formation of ester bonds between the hydroxyl group of the xyloglucan and a carboxylic acid group of the cysteine (Figure 2). In order to optimize the synthesis procedure of thiomer, the influence of $\mathrm{pH}$ of reaction mixture during coupling reaction on the amount immobilized thiol groups on xyloglucan was evaluated.

\section{Evaluation}

\section{Fourier transform infra-red spectroscopy}

FTIR studies on xyloglucan and thiomer were

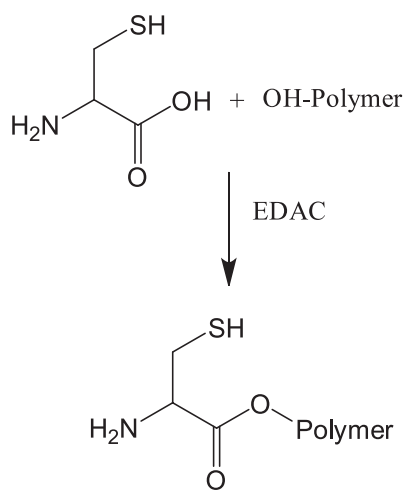

FIGURE 2 - Scheme for synthesis of xyloglucan-cysteine conjugate.

carried out in order to confirm the formation of conjugate between xyloglucan and cysteine to give thiomer. As shown in Figure 3, FTIR spectrum of xyloglucan is in agreement with reported study (Vodenicarova et al., 2006), whereas the comparison between spectra of xyloglucan and thiomer did not differ to enable a conclusion.

\section{Differential Scanning Calorimetry}

DSC studies on xyloglucan and thiomer was carried out in order to study thermal behavior of polymers. Figure 4 represents the differential scanning thermogram of thiomer (A) and xyloglucan (B) show a broad endotherm at $54{ }^{\circ} \mathrm{C}$ and $74.59{ }^{\circ} \mathrm{C}$ respectively. The thermogram of thiomer exhibit a sharp endothermic peak $212.57^{\circ} \mathrm{C}$ with heat flow $-113.96 \mathrm{~mJ} / \mathrm{g}$ which might be due to combustion of thiomer.

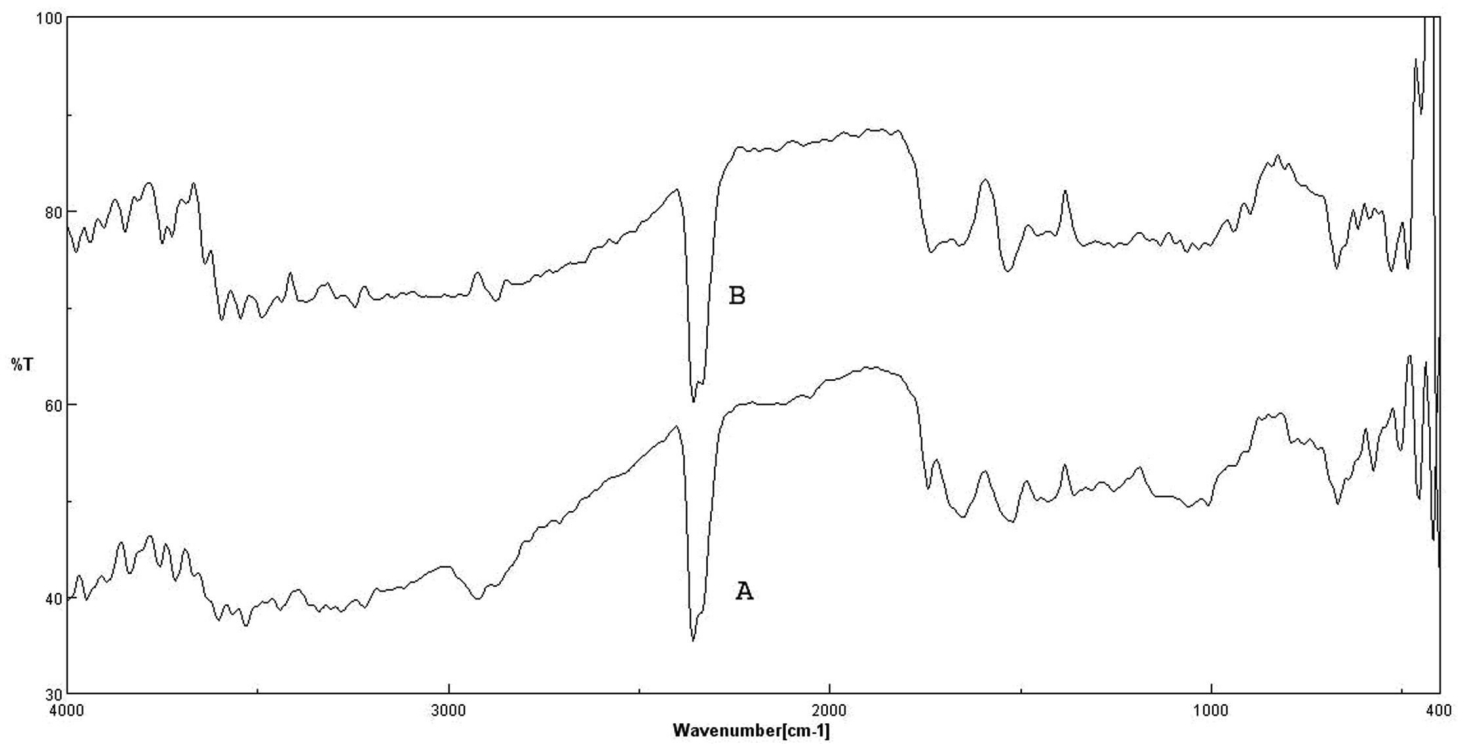

FIGURE 3 - Fourier transform infra-red spectroscopy of xyloglucan (A) and thiomer (B). 


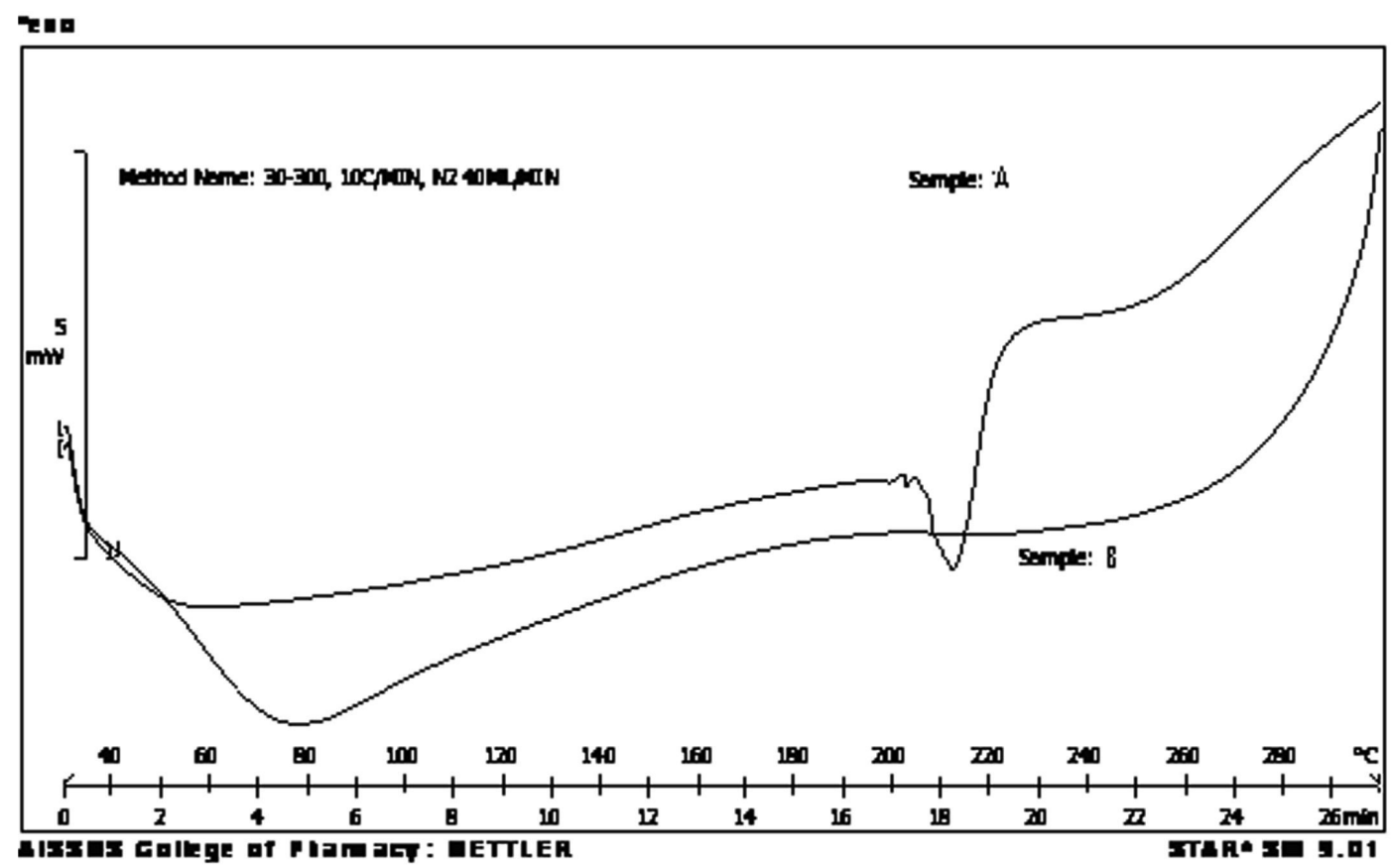

FIGURE 4 - DSC thermogram of (A) thiomer and (B) xyloglucan.

\section{Thiol and Disulphide group content}

In the $\mathrm{pH}$-range of 2-5, the bonding of thiol groups increased with increasing the $\mathrm{pH}$. At $\mathrm{pH} 2$, the low thiol incorporation on xyloglucan $(3.63 \pm 0.12 \%)$. The amount of attached thiol groups increased at $\mathrm{pH} 4(6.17 \pm 0.28 \%)$ and reached to maximum at $\mathrm{pH} 5(7.67 \pm 0.14 \%)$. In contrast, at $\mathrm{pH}$ above 5 the yield of xyloglucan bonded thiol groups decreased again. A reason for this observation can be seen in the oxidation of the sulfhydryl groups during the coupling reaction which is favored at higher $\mathrm{pH}$-values (Schmitz et al., 2008) and increased share of disulfide bond formation between two thiol groups. The differences were found to be significant after a multiple comparison test followed by Tucky test $(\mathrm{p}<0.05)$ using PRIMER software.

On the other hand disulfide group content was found to be directly related to the $\mathrm{pH}$ of reaction. The amount of disulphide groups increased at pH $5(2.29 \pm 0.06 \%)$ and reached to maximum at $\mathrm{pH} 6(3.83 \pm 0.12 \%)$ this is because hydrated and swollen matrix based on anionogenic polymers have high buffer capacity and are capable of maintaining previously adjusted $\mathrm{pH}$ value hence the values of disulphide group content increased from TH2 to TH6.

\section{Water uptake studies}

The swelling behavior of mucoadhesive polymers has a great influence on their mucoadhesive properties (Bernkop-Schnürch et al., 2000). By absorbing, swelling and capillary effects, mucoadhesive polymers are supposed to take water from the underlying mucosal tissue leading to a considerably strong adhesion (Duchene et al., 1992).

The water uptake studies carried out on xyloglucan and various thiomers showed a significant increase in water uptake till duration of the study (4 h) (Table II). The water uptake at the end of $4 \mathrm{~h}$ was more with

TABLE I - Thiol and disulphide group content of thiomers synthesized at different $\mathrm{pH}$

\begin{tabular}{lccc}
\hline Sr. no. & Type of Thiomer & \% Thiol group content & \% Disulphide group content \\
\hline 1 & TH2 & $3.63 \pm 0.12$ & $0.82 \pm 0.19$ \\
2 & TH3 & $4.95 \pm 0.1$ & $1.52 \pm 0.13$ \\
3 & TH4 & $6.17 \pm 0.18$ & $1.92 \pm 0.08$ \\
4 & TH5 & $7.67 \pm 0.14$ & $2.29 \pm 0.06$ \\
5 & TH6 & $5.90 \pm 0.08$ & $3.83 \pm 0.12$ \\
\hline
\end{tabular}

TH2, TH3, TH4, TH5 and TH6: thiomer synthesized at $\mathrm{pH}$ 2, 3, 4, 5 and 6, respectively $(\mathrm{n}=3)$ 
TABLE II - Comparison of water uptake of discs of xyloglucan prepared from xyloglucan and thiomers prepared at different $\mathrm{pH}$ (TH2 to TH6)

\begin{tabular}{lcccccc}
\hline Time & Xyloglucan & TH2 & TH3 & TH4 & TH5 & TH6 \\
\hline 30 & $2.2 \pm 0.06$ & $2.1 \pm 0.06$ & $2.1 \pm 0.06$ & $1.8 \pm 0.15$ & $1.8 \pm 0.12$ & $1.8 \pm 0.16$ \\
60 & $2.9 \pm 0.05$ & $2.6 \pm 0.05$ & $2.6 \pm 0.10$ & $2.7 \pm 0.25$ & $2.7 \pm .0 .25$ & $2.3 \pm .0 .12$ \\
90 & $3.6 \pm 0.05$ & $3.5 \pm 0.12$ & $3.2 \pm 0.15$ & $3.3 \pm 0.15$ & $3.3 \pm 0.10$ & $3.3 \pm 0.08$ \\
120 & $4.2 \pm 0.04$ & $4.3 \pm 0.38$ & $3.8 \pm 0.10$ & $3.6 \pm 0.12$ & $3.6 \pm 0.25$ & $3.6 \pm 0.12$ \\
150 & $4.8 \pm 0.03$ & $4.1 \pm 0.26$ & $4.3 \pm 0.18$ & $4.0 \pm 0.15$ & $4.0 \pm 0.21$ & $4.3 \pm 0.18$ \\
180 & $5.2 \pm 0.01$ & $4.8 \pm 0.12$ & $4.5 \pm 0.29$ & $4.2 \pm 0.23$ & $4.2 \pm 0.06$ & $4.5 \pm 0.12$ \\
240 & $5.5 \pm 0.16$ & $5.0 \pm 0.15$ & $4.8 \pm 0.12$ & $4.3 \pm 0.17$ & $4.3 \pm 0.17$ & $4.7 \pm 0.17$ \\
\hline
\end{tabular}

xyloglucan $(5.5 \pm 0.16 \%)$ and was found to decrease from TH2 $(5.1 \pm 0.5 \%)$ to TH5 $(4.3 \pm 0.17 \%)$ and increased for TH6 $(4.7 \pm 0.15 \%)$. Thus due to higher water uptake the swelling rate of xyloglucan was higher than thiomers the reason for this could be that, xyloglucan possesses groups that ionize at higher $\mathrm{pH}$ values and results into negative charge generation in the polymeric matrix, which might help in loosening of polymeric structure and helps water penetration and swelling. The swelling behavior of thiomer was strongly reduced due to the immobilization of cysteine. The increase in mucoadhesion of thiomers despite of reduced water uptake can be attributed to the covalent bonding thiol group with mucin.

\section{In vitro mucoadhesion studies}

Mucoadhesion studies carried out on xyloglucan and thiomer revealed an increase in the mucoadhesive strength of thiomer as compared to xyloglucan, the thiol/disulfide exchange reactions between the thiol groups of the thiomer and the cysteine-rich subdomains of mucin glycoproteins could be responsible for this (Constantia et al., 2002). Mucoadhesive property of thiomer is strongly dependent on $\mathrm{pH}$ of the reaction conditions and thus on the thiol group content. The results of the mucoadhesion studies (Table III) indicate that the increase in the mucoadhesive strength for TH2 was only 1.75 fold. This is occurs due to less immobilization of thiol group on to xyloglucan polymeric structure (Roldo et al., 2004). Mucoadhesion strength was found to increase as $\mathrm{pH}$ was increased and reaches maximum at $\mathrm{pH} 5.0$, but further increase in the $\mathrm{pH}$ of reaction conditions did not result into increase in mucoadhesion. Mucoadhesive strength for TH5 showed 2.90 fold increase in mucoadhesion. A reason for this observation can be seen in the fact that thiolated polymers do not only form disulfide bonds with the mucus glycoprotein but also inter and/or intrachain disulfide bonds within the polymer itself (Bernkop-Schnurch et al., 1999).
TABLE III - Comparison of mucoadhesive strength of xyloglucan and thiomer

\begin{tabular}{lcc}
\hline Type of Polymer & $\begin{array}{c}\text { Mucoadhesive } \\
\text { Strength } \\
\left(\mathbf{d y n e}_{\mathbf{c}} \mathbf{c m}^{2}\right)\end{array}$ & $\begin{array}{c}\text { Improvement in } \\
\text { Mucoadhesion }\end{array}$ \\
\hline Xyloglucan & $13083.3 \pm 874.46$ & ------ \\
TH2 & $22895.8 \pm 1282.32$ & 1.75 fold \\
TH3 & $25667.3 \pm 1634.68$ & 1.96 fold \\
TH4 & $33344.9 \pm 2284.78$ & 2.55 fold \\
TH5 & $38001.5 \pm 1542.52$ & 2.90 fold \\
TH6 & $34094 \pm 1642.24$ & 2.60 fold \\
\hline
\end{tabular}

Viscosity measurement

The solutions of xyloglucan and thiomer were prepared in $2 \%$ concentration, and their rheological properties were studied. It is clear from (Table IV) that thiolated solutions are more viscous compared to xyloglucan solution and viscosity increases with thiomer synthesized at increasing $\mathrm{pH}$. Viscosity of TH5 shows 2.92 fold increase over xyloglucan. It occurs because of the formation of disulfide bonds within the threedimensional polymeric network leads to an increased viscosity (Bernkop-Schnürch 2005).

TABLE IV - Viscosity of various thiomers at $25^{\circ} \mathrm{C}$

\begin{tabular}{lccc}
\hline Sr. No. & $\begin{array}{c}\text { Type of } \\
\text { Polymer }\end{array}$ & $\begin{array}{c}\text { Apparent } \\
\text { viscosity (cps) }\end{array}$ & $\begin{array}{c}\text { Improvement in } \\
\text { viscosity }\end{array}$ \\
\hline 1 & Xyloglucan & 390.7 & ------ \\
2 & TH2 & 788.2 & 2.02 fold \\
3 & TH3 & 892.4 & 2.28 fold \\
4 & TH4 & 964.1 & 2.47 fold \\
5 & TH5 & 1142.5 & 2.92 fold \\
6 & TH6 & 978.3 & 2.5 fold \\
\hline
\end{tabular}

TH2, TH3, TH4, TH5 and TH6: thiomer synthesized at $\mathrm{pH} 2$, $3,4,5$ and 6 , respectively 


\section{CONCLUSION}

The improvement of the mucoadhesive properties of polymers due to the immobilization of cysteine could be confirmed for tamarind seed polysaccharide though the water uptake decreased. Due to the introduction of thiol group within this polymer, its cohesiveness was greatly improved. Because of these features, thiolated polymers seem to represent a promising new generation of mucoadhesive polymers which should provide a much more prolonged residence time of drug delivery systems on various mucosal tissues compared to well establish polymers.

\section{ACKNOWLEDGEMENT}

The authors are thankful to AISSMS College of Pharmacy for providing the facilities for carrying out the research project and Bakre Starch (Malegaon, India) for providing Tamarind kernel powder.

\section{REFERENCES}

BERNKOP-SCHNÜRCH, A. Thiomers: a new generation of mucoadhesive polymers. Adv. Drug Deliv. Rev., v.57, p.1569-1582, 2005.

SCHNURCH, A.B.; STEININGER, S. Synthesis and characterisation of mucoadhesive thiolated polymers. Int. J. Pharm., v.194, p 239-247, 2000.

BERNKOP-SCHNÜRCH, A.; GERIT, H.S.; KRATZEL, M.; Modified mucoadhesive polymers for the peroral administration of mainly elastase degradable therapeutic (poly)peptides. J. Control. Release, v.47, p.113-121, 1997.

BERNKOP-SCHNÜRCH, A. Polymer-inhibitor conjugates: a promising strategy to overcome the enzymatic barrier to perorally administered (poly) peptide drugs. S.T.P. Pharm. Sci., v.9, p.78-87, 1999.

BILICIC, M.; FILIPOVIC-GRCIC, J.; MARTINAC, A.; BARBARIC, M. Synthesis and characterization of thiomers of polyaspartamide. Int. J. Pharm., v.291, p.211-219, 2005.

BORCHARD, G.; LUEBEN, H.L.; DE BOER. Effects of chitosan-glutamate and carbomer on epithelial tight junctions in vitro. J. Control. Rel., v.39, p.131-138, 1996.
CONSTANTIA, E.K.; BERNKOP-SCHNURCH, A.B. Polymer-cysteamine conjugates: new mucoadhesive excipients for drug delivery. Int. J. Pharm., v.234, p.91-99, 2002.

CONSTANTIA, E.K.; SCHNURCH, A.B. Thiolated polymers - thiomers: development and in vitro evaluation of chitosanthioglycolic acid conjugates. Biomaterials, v.22, p.23452352, 2001.

DUCHENE, D.; PONCHEL, P. Principle and investigation of the bioadhesion mechanism of solid dosage forms, a review. Biomaterials, v.10, p.709-714, 1992.

GIDLEY, M.J.; LILLFORD, P.J.; ROWLANDS, D.W.; CRESCENZI, V. Structure and solution properties of tamarind-seed polysaccharide. Carbohydr. Res., v.214, p.299-314, 1991.

GLICKSMAN, M. Tamarind seed gum. In: GLICKSMAN, M. (Ed.) Food hydrocolloids. Boca Raton: CRC Press Inc., 1996. v.3, p.191-202.

GOHEL, M.C.; PATEL, M.M.; AMIN, A.F. Development of modified release Diltiazem HCL tablet using compsite index to indentify optimal formulation. Drug Dev. Ind. Pharm., v.29, p.124-131, 2005.

GU, J.M.; ROBINSON, J.R.; LEUNG, S.H.S. Binding of acrylic polymers to mucin/epithelial surfaces: structure property relationships. Crit. Rev. Ther. Drug Carrier Systems, v.5, p.21-27, 1998.

GUM JR., J.R.; HICKS, J.W.; TORIBARA, N.W. The human $M U C 2$ intestinal mucin has cysteine-rich subdomains located both upstream and down-stream of its central repetitive region. J. Biol. Chem., v.267, p.21375-21383, 1992.

JONES, D.S.; WOOLFSON, A.D.; BROWN, A.F. Design, characterization and preliminary clinical evaluation of a novel mucoadhesive topical formulation containing tetracycline for the treatment of periodontal disease. $J$. Control. Release, v.67, p.357-368, 2000.

KAWASAKI, N.; OHKURA, R.; MIYAZAKI, S. Thermally reversible xyloglucan gels as vehicles for oral drug delivery. Int. J. Pharm., v.181, p.227-234, 1999. 
LEHR, C.M.; TIROSH, B. Bioadhesion technologies for the delivery of peptide and protein drugs to the gastrointestinal tract. Crit. Rev. Ther. Drug. Carrier Systems, v.11, p.119160, 1994.

LEITNER V.M.; WALKER G.F.; BERNKOP-SCHNURCH, A. Thiolated polymers: evidence for formation of disulphide bonds with mucus glycoproteins. Eur. J. Pharm. Biopharm., v.56, p.207-214, 2003.

LUDWIG, A. The use of mucoadhesive polymers in ocular drug delivery. Adv. Drug Deliv. Rev., v.57, p.1595-1639, 2005.

MAJITHIYA, R.J.; GHOSH, P.K.; UMRETHIA, M.L.; MURTHY, R.S.R. Thermoreversible- mucoadhesive gel for nasal delivery of sumatriptan. AAPS PharmSciTech, v.7, p.67-73, 2006.

MORTAZAVI, S.A.; SMART, J.D. An investigation of some factors influencing the in-vitro assessment of Mucoadhesion. Int. J. Pharm., v.116, p.223-230, 1995.

ROLDO, M.; HORNOF, M.; BERNKOP-SCHNURCH, A. Mucoadhesive thiolated chitosans as platforms for oral controlled drug delivery: synthesis and in vitro evaluation. Eur. J. Pharm. Biopharm., v.57, p.115-121, 2004.

SCHMITZ, T.; GRABOVAC, V.; PALMBERGER, T.F.; SCHNURCH, A.B. Synthesis and characterization of a chitosan- $N$-acetyl cysteine conjugate. Int. J. Pharm., v.347, p.79-85, 2008.
SCHNURCH,A.B.; SCHWARZ, V.; STEININGER, S. Polymers with thiol groups: a new generation of mucoadhesive polymers. Pharm. Res., v.16, p.876-881, 1991.

SCHNURCH, A.B.; STEININGER, S. Synthesis and characterization of mucoadhesive thiolated polymers. Int. J. Pharm., v.194, p.239-247, 2000.

SUMATHI, S.; RAY, A.R. Release behaviour of drugs from Xyloglucan tablets. J. Pharm. Pharm. Sci., v.5, p.12-18, 2002.

TIROSH, B. Mucus gel thickness and turnover in the gastrointestinal tract: response to cholinergic stimulus and implication for Mucoadhesion. Pharm. Res., v.11, p.794799, 1994.

VODENICAROVA, M.; DRIMALOVA, G.; HROMADKOVA, Z.; MALOVIKOVA, A.; EBRINGEROVA, A. Xyloglucan degradation using different radiation sources: a comparative study. Ultrason. Sonochem., v.13, p.157-164, 2006.

Received for publication on $30^{\text {th }}$ March 2012 Accepted for publication on $25^{\text {th }}$ October 2012 